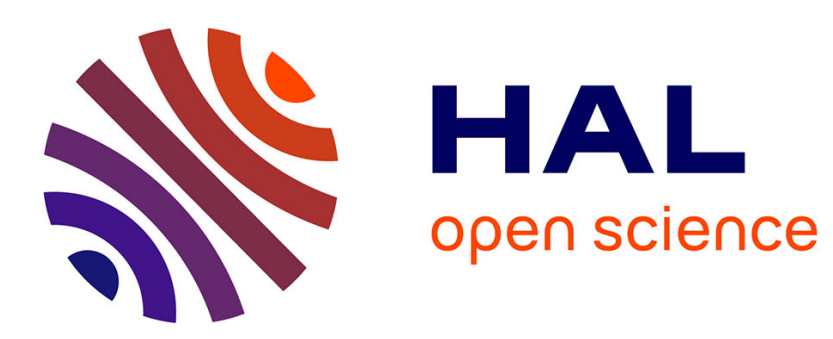

\title{
Rapid localized decline of a French Polynesian coral reef following a climatic irregularity
}

David Lecchini, Frédéric Bertucci, Rohan Brooker, Cecile Berthe, Julien Gasc, Frédérique Jossinet, Stanley Ellacott, Etienne Zipper, Guilhem Blay, Denis Schneider, et al.

\section{To cite this version:}

David Lecchini, Frédéric Bertucci, Rohan Brooker, Cecile Berthe, Julien Gasc, et al.. Rapid localized decline of a French Polynesian coral reef following a climatic irregularity. Estuarine, Coastal and Shelf Science, 2020, 246, pp.107049. 10.1016/j.ecss.2020.107049 • hal-03096452

\section{HAL Id: hal-03096452 https://hal.science/hal-03096452}

Submitted on 4 Jan 2022

HAL is a multi-disciplinary open access archive for the deposit and dissemination of scientific research documents, whether they are published or not. The documents may come from teaching and research institutions in France or abroad, or from public or private research centers.
L'archive ouverte pluridisciplinaire HAL, est destinée au dépôt et à la diffusion de documents scientifiques de niveau recherche, publiés ou non, émanant des établissements d'enseignement et de recherche français ou étrangers, des laboratoires publics ou privés. 


\title{
Rapid localized decline of a French Polynesian coral reef following a climatic irregularity
}

\author{
David Lecchini $^{\text {a,b, }{ }^{*}, 1}$, Frédéric Bertucci ${ }^{\text {c, d, } 1}$, Rohan M. Brooker ${ }^{\mathrm{e}}$, Cecile Berthe ${ }^{\mathrm{a}}$, Julien Gasc ${ }^{\mathrm{a}}$, \\ Frédérique Jossinet ${ }^{\mathrm{a}}$, Stanley Ellacott ${ }^{\mathrm{f}}$, Etienne Zipper $^{\mathrm{g}}$, Guilhem Blay ${ }^{\mathrm{h}}$, Denis Schneider ${ }^{\mathrm{i}}$, \\ Vincent Sturny ${ }^{\mathrm{j}}$, Tamatoa Bambridge ${ }^{\mathrm{a}, \mathrm{k}}$ \\ ${ }^{\text {a }}$ PSL University, EPHE-UPVD-CNRS, USR 3278 CRIOBE, 98729, Moorea, French Polynesia \\ b Laboratoire D'Excellence "CORAIL”, 66860, Perpignan, France \\ c Unité FRE BOREA, MNHN, CNRS 7208, Sorbonne University, IRD 207, University Caen Normandy, University of French West Indies, Guadeloupe \\ ${ }^{\mathrm{d}}$ Functional and Evolutionary Morphology Lab, University of Liège, 4000, Liege, Belgium \\ ${ }^{\mathrm{e}}$ Centre for Integrated Ecology, School of Life and Environmental Science, Deakin University, Geelong, VIC, Australia \\ ${ }^{\mathrm{f}}$ Cluster Maritime, 98713, Tahiti, French Polynesia \\ ${ }^{\mathrm{g}}$ Clinique Vétérinaire, 98730, Bora-Bora, French Polynesia \\ ${ }^{\mathrm{h}}$ Lagoon Service \& Reef Discovery, 98730, Bora-Bora, French Polynesia \\ ${ }^{i}$ Tahiti Bioroche, 98730, Bora-Bora, French Polynesia \\ ${ }^{j}$ Polynésienne des Eaux, 98730, Bora-Bora, French Polynesia \\ ${ }^{\mathrm{k}}$ The Rahui Forum and Resource Center, French Polynesia
}

\section{A R T I C L E I N F O}

\section{Keywords:}

Mass mortality

Hypoxia event

Harmful algal bloom

Resilience

Coral

Fish

Giant clams

\begin{abstract}
A B S T R A C T
Coral reefs are among the most biologically diverse and complex marine ecosystems on Earth. However, anthropogenic impacts continue to degrade coral reefs worldwide, potentially increasing the ability for localized climatic irregularities or fluctuations to cause rapid changes to habitats over limited spatial scales. Bora-Bora Island was impacted by one such irregularity between $02^{\text {th }}$ and January 05, 2020, with adjacent reefs subjected to a combination of low tides, high temperature and algal bloom. Our monitoring surveys showed that after only four days of these conditions, live coral cover on some Bora-Bora reefs rapidly declined from $80 \pm 7 \%$ to $20 \pm 7 \%$. In addition, the density of fishes and giant clams also decreased (i.e., respectively, from 3.6 to 6.1 individuals per $\mathrm{m}^{2}$ before climatic anomaly to 2.6 and 2.2 individuals after climatic anomaly). This study suggests that, as the mean environmental conditions continue to move towards to abiotic limits on coral reef growth and persistence, even small fluctuations above these limits could have dramatic impacts on the resilience of reef communities.
\end{abstract}

\section{Introduction}

Over the past four decades, the effects of global climate change and other anthropogenic pressures have led to the definitive loss of $20 \%$ of the world's coral reefs with the remainder increasingly at risk (Hughes et al., 2017; Morrison et al., 2019). In addition to representing one of the most biologically diverse, complex, and ecologically important marine ecosystems worldwide, coral reefs support a variety of essential socioeconomic and physical processes including food production, tourism, biotechnology, and coastal protection (Costanza et al., 2014). As many island nations, such as those within the South Pacific, are dependent on these processes for socioeconomic security (Moritz et al., 2018), there is a critical need to assess the breadth of anthropogenic effects on coral reefs to ensure effective conservation and management (Morrison et al., 2020). In addition to identifying impacts on coral reefs over broad spatial and temporal scales, there is also the need to determine the potential for local-scale impacts in areas of particular economic, cultural, or environmental importance in order to ascertain the specific consequences for the communities that rely on them (Hoegh-Guldberg et al., 2015; Rassweiler et al., 2020).

In French Polynesia, one such area is Bora-Bora, small volcanic island of $30 \mathrm{~km}^{2}$ with coral reefs amounting to an area of $78 \mathrm{~km}^{2}$ (Gabrie et al.,

\footnotetext{
* Corresponding author. PSL University, EPHE-UPVD-CNRS, USR 3278 CRIOBE, 98729, Moorea, French Polynesia.

E-mail address: david.lecchini@ephe.psl.eu (D. Lecchini).

1 Supporting authors.
} 
1994). Often called the 'Pearl of the Pacific', Bora-Bora is a major international tourist destination with the local economy dependent on the tourism and service industry (Lepresle, 2017). Bora-Bora has long featured prominently in advertising for French Polynesia as a whole, due to both its aesthetic charms as well as its commitment to environmental protection (Blondy, 2010; Lepresle, 2017). For instance, Bora-Bora is the only French Polynesian location to have received an international Blue Flag certification since 1999, a well-known international ecotourism label identifying exemplary environmental quality (Lepresle, 2017). Despite the importance of its marine environment to the French Polynesian tourism industry, the Bora-Bora reef complex has received comparatively little attention in terms of biodiversity research and monitoring (Gabrie et al., 1994; Lepresle, 2017). Consequently, changes to these environments due to anthropogenic activities are at risk of being overlooked, with likely flow-on effects for the ecosystem services they provide.

Extreme weather events and temperature abnormalities are increasing in frequency and severity as a result of climate change (Fey et al., 2015), with the large-scale spatial and temporal effects on coral reef ecosystems clearly evident (Hughes et al., 2017; Moritz et al., 2018; Morrison et al., 2019). However, as sea-surface temperatures steadily rise even short-term highly localized fluctuations in weather and oceanic conditions may have dramatic consequences for reef communities (Lecchini et al., 2020). One such irregularity appears to have occurred at Bora-Bora in early 2020. As recently shown at another French Polynesian location, Anaa atoll (Lecchini et al., 2020), rapid short-term changes to environmental conditions can have catastrophic localized impacts on remote coral reefs. To this end, we opportunistically surveyed the Bora-Bora reefs before and after this environmental abnormality in order to explore the effects of high temperature, hypoxia and algal bloom on the survival of marine species (coral, giant clams and fish). The aim of the present study is therefore to highlight how vulnerable coral reefs may be to such rapid and local threats of climate change.

\section{Materials \& methods}

Weather conditions in December/January at Bora-Bora are generally as follows: water temperatures between 26 and $28^{\circ} \mathrm{c}$, East wind at speeds of between 5 and 20 knots, wave action (South waves: $0.5-1 \mathrm{~m}$ heights, 5-15 s period; North waves: $0.5-1.5 \mathrm{~m}$ heights, $5-10 \mathrm{~s}$ period), tides between 0.1 and $0.4 \mathrm{~m}$, rainfall between 10 and $80 \mathrm{~mm}$ per day (data from windy.com). However, between $02^{\text {th }}$ and January 05, 2020, the reefs within the Matira sector of Bora-Bora lagoon (South part of island) were subjected to a short period of highly irregular environmental conditions and water parameters. Meteorological data revealed that water temperatures rose to above $32^{\circ} \mathrm{c}$ throughout this period. This increase in temperature was combined with a period of sustained northerly wind at speeds of between 16 and 27 knots and strong wave action (2-2.2 $\mathrm{m}$ wave heights, and 15-21 s wave period). Tides were unusual low $(<0.1 \mathrm{~m})$, frequently exposing corals on the back reef. There were also high levels of rainfall immediately preceding this period $(>70 \mathrm{~mm}$ per day). These unusual conditions coincided with a harmful algal bloom at the site, likely composed of diatoms, dinoflagellates or flagellates (Rodier et al., 2019). The two last hypoxic events and temperature warming known at Bora-Bora date from 1984 to 2002 (Salvat et al., 2002).

In August 2019, surveys on were conducted on SCUBA at three sites along the southern Matira sector of Bora-Bora lagoon, with both the back reef and barrier reef surveyed at each site (Fig. 1). These surveys assessed benthic community composition, fish community composition and abundance, and giant clam (Tridacna gigas) abundance. At each reef, two $20 \mathrm{~m}$ transects were placed across the reef from a haphazardly chosen location. At each $1 \mathrm{~m}$ point along the transect, the substrate underneath was recorded using the following categories: coral rubble, sand, macroalgae, and scleractininan coral to genus. In addition, the
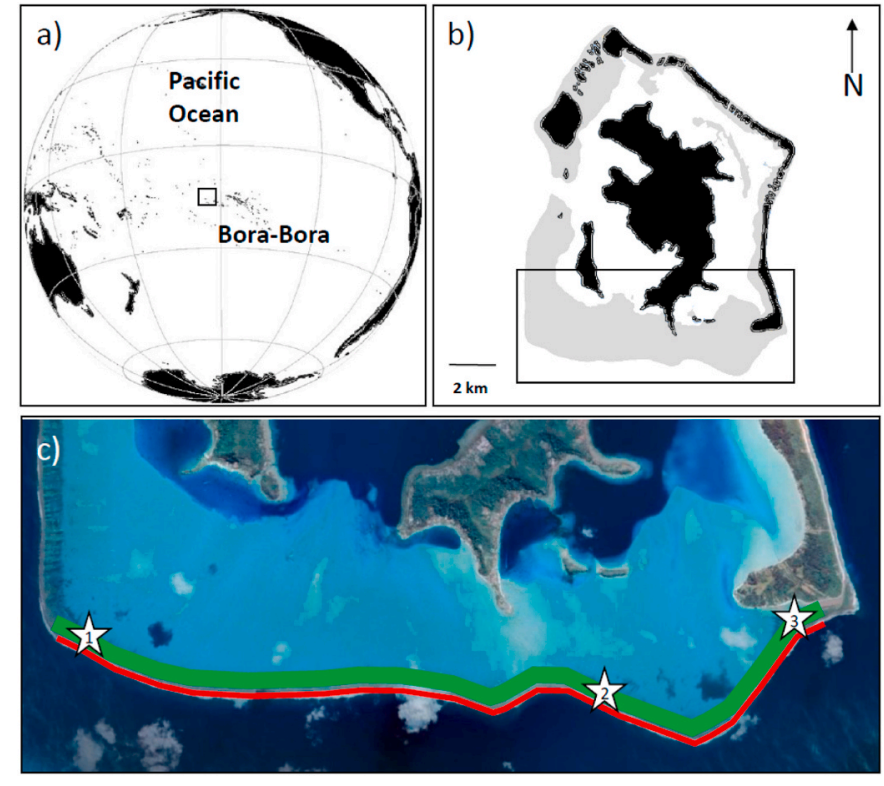

Fig. 1. Localization of Bora-Bora island in French Polynesia (South Pacific) (a, b) and map of Matira sector (c) showing the back reef and barrier reef of the three sampling sites (number in the stars). The surfaces of back reef (red line) and barrier reef (green line) are respectively, $1 \mathrm{~km}^{2}$ and $1.6 \mathrm{~km}^{2}$. On the barrier reef, the visual survey of fish, coral and giant clams were conducted on the patch reefs, and not on the coral rubble splitting the patch reefs from each other. The visual surveys were conducted on the three sites (site 1: $16^{\circ} 32^{\prime} 53.27^{\prime \prime} \mathrm{S}-151^{\circ} 47^{\prime} 12.99^{\prime \prime} \mathrm{W}$; site 2 : $16^{\circ} 33^{\prime} 9.40^{\prime \prime} \mathrm{S}-151^{\circ} 43^{\prime} 25.81^{\prime \prime} \mathrm{W}$, site 3: $16^{\circ} 32^{\prime} 51.22^{\prime \prime} \mathrm{S}-151^{\circ} 42^{\prime} 4.07^{\prime \prime} \mathrm{W}$ ), but also between the sites. (For interpretation of the references to colour in this figure legend, the reader is referred to the Web version of this article.)

condition of each coral (live or dead) was recorded. Fishes and giant clams were also surveyed along these $20 \mathrm{~m}$ transects, extended out to form a $5 \mathrm{~m}$ belt (i.e. $100 \mathrm{~m}^{2}$ sampling area). Whether giant clams observed were alive or dead was noted, while fishes were recorded to species and ontogenetic stage (adult or juvenile). Fishes were assessed over two successive passes of the transect. On the first pass, the observer recorded highly mobile fishes that were weary of the diver's presence. On the second pass, less mobile and more site-attached species were recorded. These surveys were repeated using the same methods in February 2020 following the climatic anomaly outlined above.

As the abundance of juvenile fishes varies between August and February due to annual recruitment patterns (Lecchini et al., 2004; Barth et al., 2015), we only took adult fishes into consideration. Subsequent analyses were conducted on total fish density (all species taken into consideration), on resident fish density, on butterflyfish (Chaetodontidae) density and on Stegastes spp. damselfish (Pomacentridae) density. Resident fish species belonged to the following families: Pomacentridae (all fishes except for the Stegastes species), Holocentridae, Pomacanthidae (mainly Centropyge species), Serranidae, Muranidae, Scorpaenidae, and Tetraodontidae (mainly Canthigaster species). Resident fishes are strongly associated with scleractinian coral habitats and may display limited movement following disturbance (Siu et al., 2017). As obligate and facultative corallivores, Chaetodontidae species are a good ecological indicator of living coral colonies (Thompson et al., 2019), while Stegastes species (mainly S. nigricans and S. fasciolatus) are an ecological indicator of dead coral colonies with algal turf (Tebbett et al., 2020). The percentage cover of each substrate type, the density of live or dead giant clams (number of individuals per $\mathrm{m}^{2}$ ) and number of fishes were analyzed using Wilcoxon paired tests on each habitat before and after climatic anomaly. 


\section{Results}

For substrate surveys, live coral cover decreased significantly on back reefs after the anomaly (Wilcoxon paired test, $\mathrm{V}=0, \mathrm{P}=0.035$ ). While at site 1 , live coral cover at the back reef accounted for $78 \pm 3 \%$ of the substrate in August 2019 and $73 \pm 3 \%$ in February 2020, sites 2 and 3 were more severely impacted with a reduction in live coral cover from $78 \pm 11 \%$ to $28 \pm 3 \%$ and from $80 \pm 7 \%$ to $20 \pm 7 \%$ respectively. In parallel, the proportion of dead coral increased significantly on back reefs, mainly on sites 2 and 3 (Wilcoxon paired test, $\mathrm{V}=21, \mathrm{P}=0.035$ ) (Fig. 2a). On the barrier reefs, live coral (Wilcoxon paired test, $\mathrm{V}=10, \mathrm{P}$ $=0.59$ ) and dead coral (Wilcoxon paired test, $\mathrm{V}=15, \mathrm{P}=0.39$ ) covers did not vary significantly, even though site 3 displayed a drastic decrease from $65 \pm 7 \%$ to $15 \pm 1 \%$ (Fig. 2b). Among coral genera, Pocillopora and Acropora were the most impacted (no live corals from these genera were observed alive in February 2020 at sites 2 and 3 on the back reefs) in comparison to Porites and Montipora.

While not significant, the abundance of live giant clams tended to decrease on back reefs (Wilcoxon paired test, $\mathrm{V}=2, \mathrm{P}=0.09$ ). The density at site 1 did not change, with 2.1 individuals per $\mathrm{m}^{2}$ in August 2019 and 2.2 individuals per $\mathrm{m}^{2}$ in February 2020 (Fig. 3a). In contrast, there was a notable drop on sites 2 and 3 , with density decreasing from 1.2 to 0.05 individuals per $\mathrm{m}^{2}$ at site 2 , and from 2.7 to 0.01 individuals per $\mathrm{m}^{2}$ at site 3 (Fig. 3a). Moreover, the density of dead giant clams increased significantly on back reefs $(\mathrm{V}=21, \mathrm{P}=0.035)$ as no dead individuals were found in August 2019 in any site and up to 0.22 dead individuals per $\mathrm{m}^{2}$ could be observed in site 2 in February 2020. On the barrier reef, no significant difference was found for live and dead giant clams ( $\mathrm{V}=6, \mathrm{P}=0.43 ; \mathrm{V}=10, \mathrm{P}=0.09$, respectively) (Fig. 3b).

For fishes, total abundance on back reefs decreased significantly
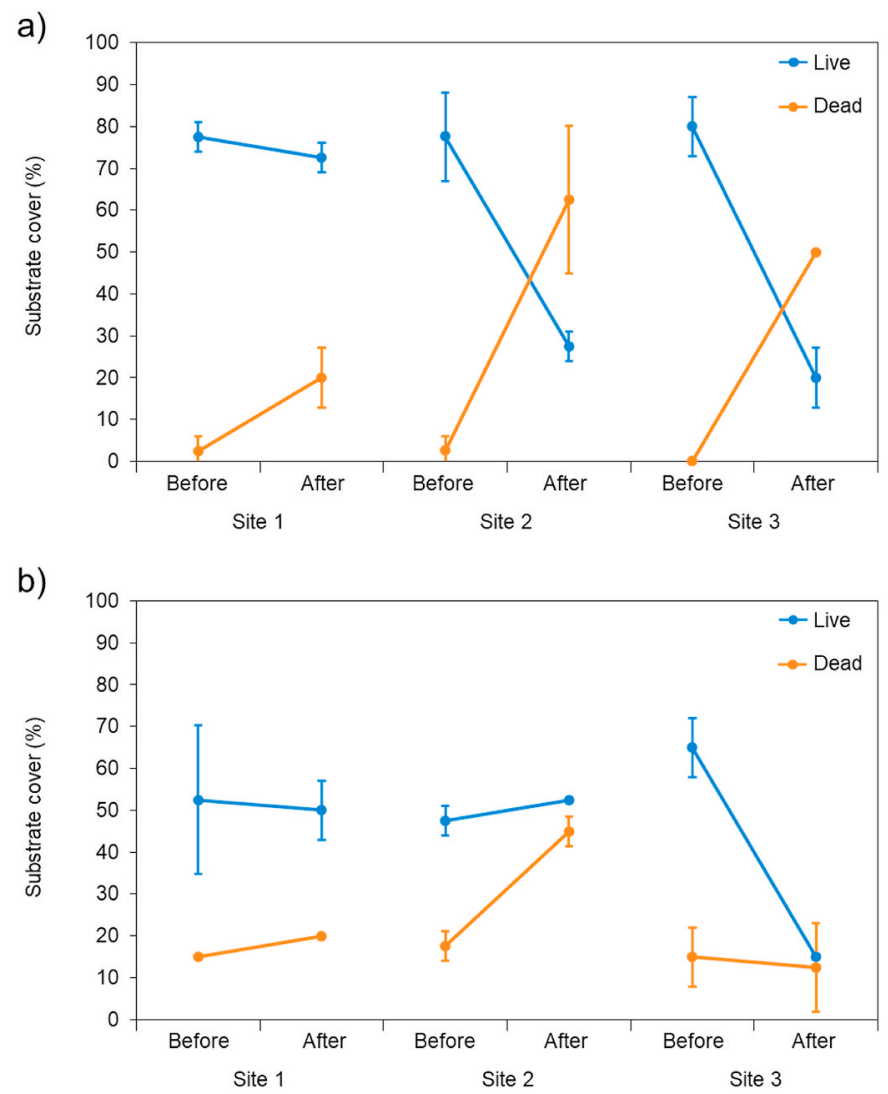

Fig. 2. Substrate cover (\%) of live coral and dead coral recorded at a) the back reef and b) the barrier reef before (August 2019) and after (February 2020) the climatic anomaly on the three sites at Bora-Bora (Matira sector). Values are mean \pm SD.
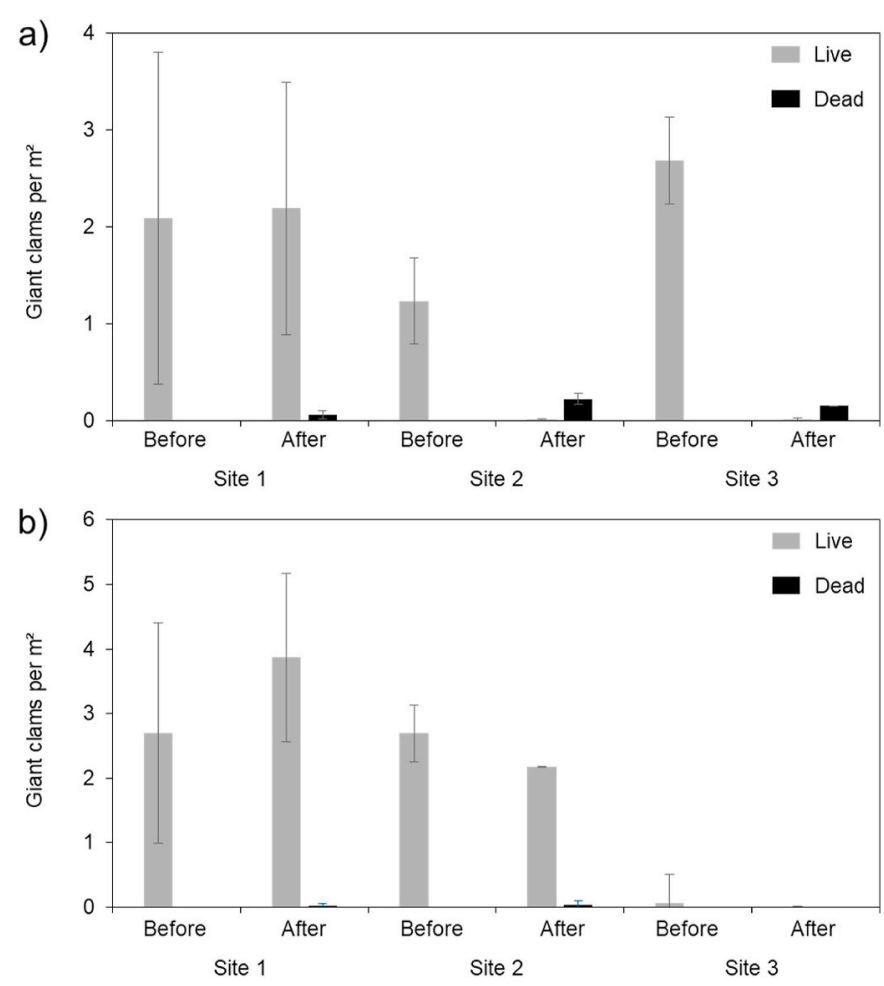

Fig. 3. Density of live and dead giant clams on a) the back reef and b) the barrier reef before (August 2019) and after (February 2020) the climatic anomaly on the three sites. Values are mean \pm SD.

(Wilcoxon paired test, $\mathrm{V}=0, \mathrm{P}=0.031$ ), from 1.7 to 1.3 fishes per $\mathrm{m}^{2}$ on site 1 , from 0.8 to 0.5 fish per $\mathrm{m}^{2}$ on site 2 , and from 1.1 to 0.3 fish per $\mathrm{m}^{2}$ on site 3 before and after the climatic anomaly (Table 1 ). Species richness also decreased significantly $(\mathrm{V}=1, \mathrm{P}=0.05)$. While it remained similar at site 2 , it decreased from 26.5 to 16.5 species on site 1 and from 18 to 6.5 species at site 3 (Table 1). In contrast, the total abundance $(\mathrm{V}=18, \mathrm{P}=0.15)$ and species richness $(\mathrm{V}=10, \mathrm{P}=1)$ did not change on barrier reef for the three sites (Table 1 ). Surprisingly, the density of Chaetodon species did not vary between sites at both habitats $(\mathrm{V}=10-12.5, \mathrm{P}=0.1-0.75)$. In contrast, the variation in the density of resident fish and Stegastes species was not uniform between sites. While they increased on site 1 , they decreased on sites 2 and 3 but not significantly ( $\mathrm{V}=4.5-12.5, \mathrm{P}=0.24-0.75)$. Lastly, the visual surveys were conducted between the three sites, and also all around Bora-Bora lagoon. We did not observe any mortality of coral, fish and giant clams outside the Matira sector.

\section{Discussion}

Our study highlights that only four days of irregular environmental conditions was sufficient to cause a dramatic change in affected coral reef communities at Bora-Bora. Mass mortality, often due to temperature abnormalities and extreme hypoxic conditions (Altieri et al., 2017), have been previously showed in marine species on India coastline (Sachithanandam et al., 2017), in coral reefs of Jarvis Island (central Pacific - Vargas-Angel et al., 2019) or in reef fish adult in Cocos Islands (Hobbs and Macrae, 2012). Unfortunately, these dramatic mass mortality events of marine species are occurring at an increasing rate (Fey et al., 2015; Lecchini et al., 2020). In our Bora-Bora surveys, live coral cover reduced significantly, with Pocillopora and Acropora species especially affected (Fig. 2). DeCarlo et al. (2017) showed a similar mass coral mortality at Dongsha Atoll (South China Sea). An unusually weak winds regime created low-flow conditions that amplified the $2{ }^{\circ} \mathrm{C}$ basin-scale anomaly. Mass coral bleaching quickly ensued, killing 40\% 
Table 1

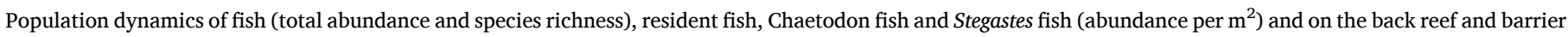

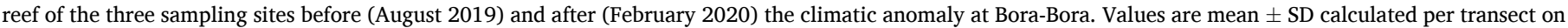
each habitat and each site.

\begin{tabular}{|c|c|c|c|c|c|c|c|}
\hline & Site & & Total abundance & Species richness & Resident species & Chaetodontidae & Stegastes sp. \\
\hline \multirow[t]{6}{*}{ Back reef } & 1 & Before & $1.73 \pm 0.40$ & $0.26 \pm 0.02$ & $0.13 \pm 0$ & $0.11 \pm 0.05$ & $0.08 \pm 0.11$ \\
\hline & & After & $1.26 \pm 0.11$ & $0.17 \pm 0.02$ & $0.25 \pm 0.04$ & $0.10 \pm 0.01$ & $0.10 \pm 0.03$ \\
\hline & 2 & Before & $0.88 \pm 0.03$ & $0.19 \pm 0.06$ & $0.16 \pm 0.06$ & $0.11 \pm 0.03$ & $0.08 \pm 0.03$ \\
\hline & & After & $0.52 \pm 0.20$ & $0.19 \pm 0.03$ & $0.03 \pm 0.03$ & $0.15 \pm 0.01$ & $0.03 \pm 0.03$ \\
\hline & 3 & Before & $1.08 \pm 0.01$ & $0.18 \pm 0.03$ & $0.14 \pm 0.12$ & $0.13 \pm 0.04$ & $0.15 \pm 0.07$ \\
\hline & & After & $0.32 \pm 0.08$ & $0.07 \pm 0.02$ & $0.04 \pm 0.01$ & $0.13 \pm 0.04$ & $0.01 \pm 0.01$ \\
\hline \multirow[t]{6}{*}{ Barrier reef } & 1 & Before & $1.14 \pm 0.87$ & $0.20 \pm 0.04$ & $0.17 \pm 0.05$ & $0.05 \pm 0.01$ & $0.08 \pm 0.03$ \\
\hline & & After & $1.72 \pm 0.06$ & $0.22 \pm 0.03$ & $0.74 \pm 0.21$ & $0.11 \pm 0.03$ & $0.16 \pm 0.15$ \\
\hline & 2 & Before & $0.88 \pm 0.47$ & $0.16 \pm 0.03$ & $0.37 \pm 0.26$ & $0.06 \pm 0.01$ & $0.06 \pm 0.06$ \\
\hline & & After & $1.02 \pm 0.03$ & $0.08 \pm 0.02$ & $0.20 \pm 0.01$ & $0.15 \pm 0.01$ & $0.12 \pm 0.03$ \\
\hline & 3 & Before & $0.07 \pm 0.08$ & $0.02 \pm 0.01$ & $0.04 \pm 0.05$ & 0 & 0 \\
\hline & & After & $0.51 \pm 0.18$ & $0.06 \pm 0.01$ & $0.01 \pm 0.01$ & 0 & 0 \\
\hline
\end{tabular}

of the resident coral community (Acropora more impacted than Porites) in an unprecedented event within the past 40 years. At Bora-Bora, the two last hypoxic events and temperature warming date from 1984 to 2002 (Salvat et al., 2002). At both dates, a period of meteorological calm combined with heavy precipitations, high sea-water temperatures (maximum temperature of $34^{\circ} \mathrm{C}$ in January 2002) and the absence of swell from the south caused a dystrophic crisis with the development of bacteria and phytoplankton (dominated by dinoflagellates with diatoms). The harmful algal bloom leaded the anoxia of the environment, the bleaching event of corals (all species except Porites and Psammocora) and the mass mortality of fish and macro-invertebrates, but only on the South part of Island (Salvat et al., 2002). In January 2020, the low tide coupled with an algal bloom induced water hypoxia and the death of fish and giant clams, especially on the back reef $(<20 \mathrm{~cm}$ water depth vs $1 \mathrm{~m}$ depth on the barrier reef). Almost all giant clams died on back reefs (Fig. 3) and fish abundance and density decreased strongly between August 2019 and February 2020 (Table 1). However, the increased number of dead giant clams were low (in abundance) compared to the decrease of living giant clams since only the recently dead clams that were still fixed on the reef with their muscle were recorded. It was impossible to know the date of clams' mortality found on sand or rubble after the January and if this was due to the climatic anomaly or rather fishing. The main fish species affected by water hypoxia were resident species from families such as Pomacentridae (including Stegastes species), Holocentridae, Pomacanthidae, Serranidae, Muranidae, Scorpaenidae and Tetraodontidae (Canthigaster). These fish species are strongly associated to a coral habitat and so would be unlikely to move away from back reef to avoid the hypoxia.

Overall, our results provide further evidence that critical components of reef communities, such as corals, giant clams and fishes from remote parts of the Central Pacific Ocean are not isolated from the effects of global climate anomalies (Moritz et al., 2018; Rassweiler et al., 2020). Indeed, despite a variety of local conservation initiatives at Bora-Bora since 2002 (e.g., fishing restrictions, collective wastewater network, coral replenishment, establishment of a marine education area - Lepresle, 2017), this study highlights that coral reefs remain particularly vulnerable to rapid and local threats linked to global climate change. Thus, this study highlights one essential but somehow under investigated question concerning both marine and terrestrial environments. What is the potential of resilience of an ecosystem exposed to such short term spectacular events compared to more long term ones? There is a need to better understand the impact of such short but strong climatic anomalies on the resilience of coral reef ecosystems and their consequences for the people who depend on their resources in order to formulate management strategies that can reduce their vulnerability over time (Moritz et al., 2018).

\section{Author statement}

FB, FJ, DS, VS, TB and DL contributed to the conception of the research. CB, JG, FJ and DL collected the data. FB, RMB, SE, EZ, GB and DL led the writing of the manuscript, produced the figures and analyzed the data. All co-authors contributed to preparation, editing and refining the concepts and text in the manuscript. All authors have seen and approved the final manuscript.

The corresponding author is responsible for ensuring that the descriptions are accurate and agreed by all authors. The authors declare that they have no known competing financial interests or personal relationships that could have appeared to influence the work reported in this paper.

\section{Declaration of competing interest}

The authors declare that they have no known competing financial interests or personal relationships that could have appeared to influence the work reported in this paper.

\section{Acknowledgments}

The study was funded by: Polynésienne des Eaux, Mairie de BoraBora, Fondation de France (2019-08602), Ministère de l'Economie verte et du domaine - Délégation à la recherche de Polynésie française (contrat N3622 MED-EPHE), LabEx CORAIL (project 2018 Emul), ANR-19CE34-0006-Manini, ANR-19-CE14-0010-SENSO, the Rāhui Forum and Ressource Center supported by Bloomberg's Philanthropy.

\section{Appendix A. Supplementary data}

Supplementary data to this article can be found online at https://doi. org/10.1016/j.ecss.2020.107049.

Hoegh-Guldberg et al., 2015

\section{References}

Altieri, A.H., Harrison, S.B., Seemann, J., Collin, R., Diaz, R.J., Knowlton, N., 2017. Tropical dead zones and mass mortalities on coral reefs. Proc. Natl. Acad. Sci. Unit. States Am. 114, 14-20.

Barth, P., Berenshtein, I., Besson, M., Roux, N., Parmentier, E., Banaigs, B., Lecchini, D., 2015. From the ocean to a reef habitat: how do the larvae of coral reef fishes find their way home? Life Environ. 65, 91-100.

Blondy, C., 2010. Les territoires touristiques polynésiens : une lecture géographique de la participation de la société locale au système touristique. thèse de doctorat, Bordeaux III, p. 781.

Costanza, R., de Groot, R., Sutton, P., der Ploeg, S., Anderson, S.J., Kubiszewski, I., Farbere, S., Turner, K., 2014. Changes in the global value of ecosystem services. Global Environ. Change 26, 152-158.

DeCarlo, T.M., Cohen, A.L., Wong, T.F., Davis, K.A., Soong, K., 2017. Mass coral mortality under local amplification of $2{ }^{\circ} \mathrm{C}$ ocean warming. Sci. Rep. 7, 44586.

Fey, S.B., Siepielski, A.M., Nussle, S., Cervantes-Yoshida, K., Hwan, J.L., Huber, E.R., Fey, M.J., Catenazzi, A., Carlson, S.M., 2015. Recent shifts in the occurrence, cause, 
and magnitude of animal mass mortality events. Proc. Natl. Acad. Sci. U.S.A. 112, 1083-1088.

Gabrie, C., Planes, S., Baldwin, J., Bonvallot, J., Chauvet, C., Vernaudon, Y., Payri, C., Galzin, R., 1994. Study of the coral reefs of Bora-Bora (society Archipelago, French Polynesia) for the development of a conservation and management plan. Ocean Coast Manag. 25, 189-216.

Hobbs, J.P.A., Macrae, H., 2012. Unusual weather and trapped coral spawn lead to fish kill at a remote coral atoll. Coral Reefs 31, 961.

Hoegh-Guldberg, O., Tanzer, J.G., Paul, Burgener, 2015. In: Reviving the Ocean Economy: the Case for Action - 2015. WWF International, Valérie Gland, Switzerland, p. 60.

Hughes, T.P., Kerry, J.T., Álvarez-Noriega, M., 2017. Global warming and recurrent mass bleaching of corals. Nature 543, 373-37.

Lecchini, D., Dufour, V., Carleton, J., Strand, S., Galzin, R., 2004. Estimating the patch size of larval fishes during colonization on coral reefs. J. Fish. Biol. 65, 1142-1146.

Lecchini, D., Bertucci, F., Almany, J., Beaury, J.P., Bagnis, H., 2020. Mass mortality in a marine educational area on a remote South Pacific atoll. Mar. Pollut. Bull. 151, 110836.

Lepresle, A., 2017. Bora-Bora: la première née. Api Tahiti, 187pp.

Moritz, C., Vii, J., Lee Long, W., Tamelander, J., Thomassin, A., Planes, S., 2018. Status and trends of coral reefs of the Pacific. GCRMN, 114p.

Morrison, T.H., Hughes, T.P., Adger, W.N., Brown, K., 2019. Save reefs to rescue all ecosystems. Nature 573, 334-336.
Morrison, T.H., Adger, N., Barnett, J., Brown, K., Possingam, H., Hughes, T., 2020. Advancing coral reef governance into the Anthropocene. Earth 2, 64-74.

Rassweiler, A., Lauer, M., Lester, S.E., 2020. Perceptions and responses of Pacific Island Fishers to changing coral reefs. Ambio 49, 130-143.

Rodier, M., Longo, S., Henry, K., Ung, A., 2019. Diversity and toxic potential of algal bloom-forming species from Takaroa lagoon (Tuamotu, French Polynesia): a field and mesocosm study. Aquat. Microb. Ecol. 83, 15-34.

Sachithanandam, V., Mageswaran, T., Sridhar, R., Arumugam, K., Purvaja, R., Ramesh, R., 2017. Rapid assessment on mass mortality of fishes in Ennore estuary of Tamil Nadu. Indian J. Geo. Mar. Sci. 46, 1647-1650.

Salvat, B., Chancerelle, Y., Schrimm, M., Morancy, R., Porcher, M., Aubanel, A., 2002. Restauration d'une zone corallienne degrade et implantation d'un jardin coralline à Bora-Bora. Rev. Ecol. 9, 81-96.

Siu, G., Bacchet, P., Bernardi, G., Brooks, A.J., Carlot, J., Causse, R., Claudet, J., Clua, E., Delrieu-Trottin, E., et al., 2017. Shore fishes of French Polynesia. Cybium 41, 245-278.

Tebbett, S.B., Chase, T.J., Bellwood, D.R., 2020. Farming damselfishes shape algal turf sediment dynamics on coral reefs. Mar. Environ. Res. 160, 104988.

Thompson, C.A., Matthews, S., Hoey, A.S., 2019. Changes in sociality of butterflyfishes linked to population declines and coral loss. Coral Reefs 38, 527-537.

Vargas-Angel, B., Huntington, B., Brainard, R.E., Venegas, R., Oliver, T., Barkley, H., Cohen, A., 2019. El nino-associated catastrophic coral mortality at Jarvis island, central equatorial Pacific. Coral Reefs 12, 1-9. 